\title{
Storytelling and policy change in Africa's Great Lakes Region
}

\author{
Chi-Chi Undie \\ Population Council \\ Nathan Byamukama \\ George Odwe \\ Population Council \\ Nachela Chelwa \\ Population Council \\ Harriet Birungi \\ Population Council
}

See next page for additional authors

Follow this and additional works at: https://knowledgecommons.popcouncil.org/departments_sbsr-rh

Part of the Demography, Population, and Ecology Commons, Domestic and Intimate Partner Violence Commons, Family, Life Course, and Society Commons, Gender and Sexuality Commons, International Public Health Commons, and the Medicine and Health Commons How does access to this work benefit you? Let us know!

\section{Recommended Citation}

Undie, Chi-Chi, Nathan Byamukama, George Odwe, Nachela Chelwa, Harriet Birungi, and Michael Mbizvo. 2019. "Storytelling and policy change in Africa's Great Lakes Region," Sauti/VOICE Program Brief no. 2. Nairobi: ICGLR-RTF and Population Council. 


\section{Authors}

Chi-Chi Undie, Nathan Byamukama, George Odwe, Nachela Chelwa, Harriet Birungi, and Michael Mbizvo 


\section{Storytelling and Policy Change in Africa's Great Lakes Region}

\section{Introduction}

What leads to sexual and gender-based violence (SGBV) policy formulation? What prompts decision-makers to change policy, or to formulate new policies to address this form of violence? Due to the role of sound policy in informing programming for critical public health issues, this causality question has been repeatedly explored in public health, and has generated several answers. In summary, policy change is often nonlinear and unpredictable: There is no real blueprint for such change. Policy change can occur in response to research and programmatic evidence-or not. Policy formulation and change can occur through meaningful relationships purposefully nurtured with key stakeholders (including policymakers), or information exchange and dialogue among such stakeholders-but there are no guarantees, and no universal guidance.

\section{A Regional Convening of Decision-Makers}

During an April 2019 regional meeting of the International Conference on the Great Lakes Region's Regional Training Facility (ICGLR-RTF) and the Population Council, in Kigo, Uganda, 'storytelling' was not foremost on the agenda. Personal narratives were included in the program of events, but only as one of many different presentations, the bulk of which were by senior Member State delegates from the Police and Health sectors. The meeting was designed to inform Police Chiefs and National Reproductive Health Division Heads from the Great Lakes Region about a police-led intervention, developed and tested by a collaborative of partners, including the Population Council, Zambia Police Service, and Zambia Ministry of Health. Developed in response to

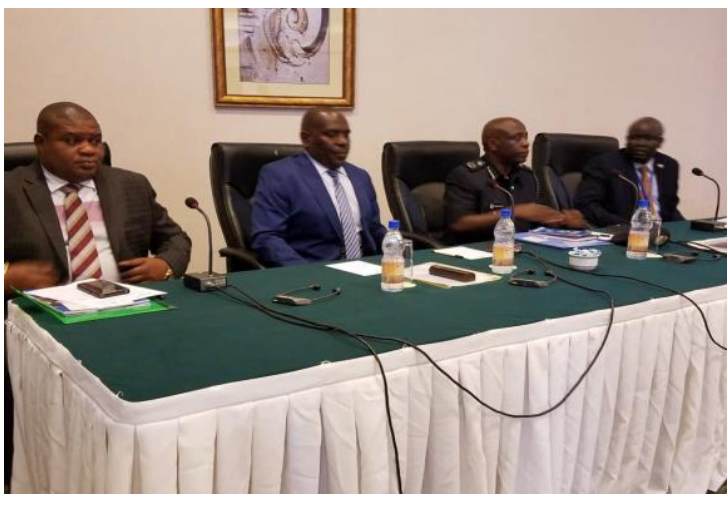

Senior police delegates from the region, including Inspectors General of Police from the Democratic Republic of Congo ((General Philemon Patience, far left) and South Sudan (General Majak Malik, far right) evidence from Zambia demonstrating that rape survivors tended to present at police stations for services without also presenting at health facilities for care, the intervention trains police officers to offer emergency contraception to sexual violence survivors, and to refer them to health facilities for comprehensive care. This police-led response model helps avert unintended pregnancy among survivors, while responding to other health issues that may arise.

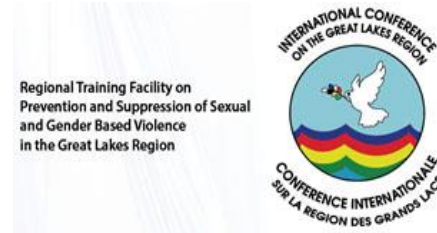




\section{A Survivor's Story}

At this high-level regional meeting of senior officials, featuring scientific and programmatic presentations from Member States, what captivated the audience of Police Chiefs and others was the personal testimony of a sexual violence survivor from the Great Lakes Region. The survivor -'Njeri', from Kenya - began her personal story by admitting to her deep fear of police due to a past experience with a police officer.

About a decade ago, Njeri traveled from one town to another in response to a job advertisement. At the office where she was to have a job interview, she was raped at knifepoint, and then ordered to leave the premises. The incident confounded her prior notions of rape: It happened in the daytime in a busy, high rise office building, while she was formally dressed for a job interview.

The incident also de-stabilized Njeri's pre-conceived notions about support available to survivors of sexual violence. At a police station close to the office building, she asked specifically for a female police officer. The female police officer on duty dismissed her, despite Njeri's pleas to investigate her case by going to the nearby office building; it was a Friday and the officer was heading to the port for other business. She told Njeri to return on Monday.

Traumatized and weary, and in the absence of information and support, Njeri left the police station, took a shower, washed her clothes, and traveled back home. Several weeks later, she began feeling nauseated and later discovered she was pregnant. She became suicidal, and made several unsuccessful attempts to terminate the pregnancy at home. Fortunately, a friend whom she confided in referred her to the Genderbased Violence Recovery Centre (GBVRC) - a one-stop SGBV response center at Kenyatta National Hospital in Nairobi, Kenya. The GBVRC essentially became a home to her, and its psychosocial support staff supported her for years, including throughout her pregnancy. Njeri gave birth to a baby boy, and it took several years of intensive counseling before she could begin to love him. While her son brings her much joy today, the Zambia-designed police-led intervention would have ensured her timely receipt of emergency contraception and other services, and would have made a difference in her life, had it been available.

The response of Police Chiefs to this personal story was unprecedented. Several apologies were offered to Njeri by Police attendees for the system's failure about a decade ago. During a final session on meeting resolutions, Police Chiefs repeatedly referred to various aspects of Njeri's story, employing them as the rationale for many final resolutions for the region.

What leads to sexual violence policy formulation? Sometimes, a story, a human face, and a tested solution are all policy-makers need to take urgent action.

\section{Regional Resolutions}

\section{Background}

From April 8-9, 2019 the ICGLR-RTF organized a regional convening entitled, 'Sensitization Meeting for Police Chiefs and National Reproductive Health Heads in the Great Lakes Region.' Held in Kigo, Uganda, the meeting brought together Chiefs of Police and Heads of Reproductive Health Departments (Ministries of Health) from 9 ICGLR Member States, namely: Burundi, Central African Republic, Republic of Congo, Democratic Republic of Congo, Kenya, South Sudan, Sudan, Uganda, and Zambia.

The meeting was sponsored by the Population Council, Kenya.

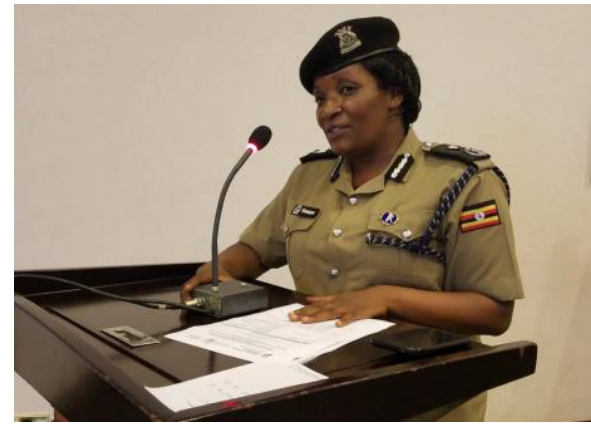

Deputy Police Spokesperson, Uganda, ACP Polly Namaye, chairing a meeting session. 


\section{Preamble to ICGLR-RTF's Meeting Resolutions}

- Recognizing that SGBV is a pervasive problem in all ICGLR Member States, adversely affecting the lives of citizens

- Acknowledging the urgent health and psychosocial support needs of survivors

- Realizing that Police provision of emergency contraception (EC) to sexual violence survivors has been tested elsewhere in the region (Zambia and Malawi) and has been proven feasible and effective, and

- We (Member States) agree on the following resolutions, urging the following:

\section{Resolutions}

1. ICGLR-RTF to support the training of a range of professionals to ensure establishment of a multisectoral approach in the Great Lakes Region to combat SGBV

2. Chiefs of Police in the Member States will integrate EC provision by trained police officers to sexual violence survivors at police station services in the region

3. ICGLR-RTF and its partners will support Member States to affect such integration

4. Chiefs of Police in the Member States will work with ministries of Health to formulate a working relationship that facilitates such integration

5. ICGLR-RTF and its partners will support the conduct of formative research in selected countries to generate information to facilitate adaptation of the police EC provision model

6. ICGLR-RTF will standardize SGBV training curricula for the Police and Health sectors in the Great Lakes Region

7. ICGLR-RTF will integrate the police EC provision model within its existing training curricula

8. The Population Council will widely disseminate research findings of the police EC provision model in the Great Lakes Region, and will continue to generate and share other SGBV-related evidence

9. Chiefs of Police in the Member States will ensure the creation of safe spaces for attending to survivors (including both physical spaces and police attitudes), and

10. Member States to strengthen mechanisms for handling SGBV perpetrators to bring them to justice and fight impunity.

\section{Next Steps}

The regional resolutions will be employed as an advocacy tool by ICGLR-RTF and its partners (including the Population Council) to promote utilization of the police EC provision model in the region, including in refugee contexts. 


\section{References}

ICGLR-RTF and Population Council. 2019. Meeting Report of the International Conference on the Great Lakes Region's Regional Training Facility: Working with the Police Sector to Meet the Needs of Sexual Violence Survivors in the Great Lakes Region. ICGLR-RTF and Population Council.

Jill Keesbury, Mary Zama, Sudha Shreeniwas. 2009. The Copperbelt Model of Integrated Care for survivors of rape and defilement: Testing the feasibility of police provision of emergency contraceptive pills. Population Council: Lusaka. www.popcouncil.org/uploads/pdfs/2009RH ZambiaCopperbeltModellntCare.pdf

Sally Theobald, Olivia Tulloch, Joanna Crichton et al. 2011. Strengthening the research to policy and practice interface: Exploring strategies used by research organisations working in sexual and reproductive health and HIV/AIDS. Health Research Policy and Systems 9 (Supplement 1): 2-7. https://health-policysystems.biomedcentral.com/articles/10.1186/1478-4505-9-S1-S2.

Since 2006, the Population Council-led Africa Regional SGBV Network has worked to build effective responses to SGBV in low-resource settings, focusing on those who have experienced violence, as well as on violence prevention. From 2018-2020, the network is collaborating with the Regional Training Facility of the International Conference on the Great Lakes Region (ICGLR-RTF) in Kampala, Uganda, and with the UNHCR EHAGL Africa Bureau in Nairobi, Kenya to address the needs of survivors in refugee settings in the East, Horn, and Great Lakes Regions of Africa through the ViOlence Response and Prevention through Information, Communication, and Education (VOICE) project. 'Voice' is translated as 'Sauti' in Kiswahili, and represents the project's emphasis on amplifying the voices of SGBV survivors and the efforts of those that work with them, to broaden the reach of effective SGBV responses across the region.

(C) 2019 ICGLR Regional Training Facility and the Population Council, Inc.

Citation: Chi-Chi Undie, Nathan Byamukama, George Odwe, Nachela Chelwa, Harriet Birungi, Mike Mbizvo (2019). 'Story-telling and policy change in the Great Lakes Region of Africa.' The Sauti/VOICE Program Brief Series, Brief No. 2. ICGLR-RTF and Population Council.

\section{ICGLR-RTF Contact:}

Nathan Byamukama

Regional Training Facility

Yusufu-Luwaga Lane

Plot 1349

P.O. Box 1386

Kampala, Uganda

nathan.byamukama@icg|r-rtf.org

\author{
Africa Regional SGBV Network Contact: \\ Chi-Chi Undie \\ Population Council \\ Avenue 5, Rose Avenue \\ Hurlingham \\ P.O. Box 17643-00500 \\ Nairobi, Kenya \\ cundie@popcouncil.org
}

